\title{
The Political Economy of Industrial Development in Pakistan: A Long-Term Perspective
}

\author{
Imran Ali and Adeel Malik**
}

\begin{abstract}
Private industrial development in Pakistan has a mixed track record. This paper presents a political economy overview of industrial development in Pakistan. Starting with an analysis of initial conditions, such as low levels of urbanization and out-migration of bourgeoisie, the paper looks at the ways in which policies were used to create advantages for elites and special interests. The paper also investigates the role of foreign aid in distorting industrial structure.
\end{abstract}

JEL Classification: F14, F19.

Keywords: Development, industrial policy, Pakistan.

This paper is motivated by a fundamental question: Why has private industrial activity failed to take off at a significant scale in Pakistan? The story of failed industrial development in Pakistan is couched in a historical and political economy narrative. Pakistan has an unenviable record of industrial development. The country's private sector is weak, dependent on state patronage, and prone to structural deficiencies. The manufacturing sector has a narrow base, concentrated mainly in the textile sector, and suffers from low profitability. Manufacturing sector investment has more or less stagnated during the past two decades. These weaknesses combined with endemic political instability, defective public infrastructure and unfavorable investment climate have stunted industrial growth. As a result, Pakistan's industrial sector has neither promoted growth nor helped to reduce poverty on a sustainable basis. It is unprepared to meet the challenges thrown up by globalization.

Existing research on this subject has tended to locate these failures in policy errors. It describes how the first attempt at industrialization in the 1960 s proved to be short-lived, and how nationalization in the 1970 s and

\footnotetext{
${ }^{*}$ Lahore University of Management Sciences.

** Oxford Centre for Islamic Studies, Department of International Development (QEH), St. Peter's College, University of Oxford.
} 
liberalization of the late 1980s resulted in little meaningful change. Current research emphasises policies, their impact and economic dimensions of the problem. But, however flawed, policy choices are endogenous to political interests, which are often more resistant to change. Even when pursued for public interest, policies can be hijacked by private political interests. The effectiveness of state-in market interventions or insulation from private interests-hinges on state capacity. Whether a state is patrimonial or developmental is in turn determined by its 'core character', which as Atul Kohli correctly points out, is 'acquired' a long time ago, often originating under colonial rule.

Once acquired during colonial rule, the 'core institutional characteristics' have proved difficult to change and displayed considerable persistence. With a few exceptions, analysis of industrial development has often neglected this lingering influence of colonialism in shaping elite interests and patterns of state authority. The present paper aims to fill this gap by providing a more integrated, and possibly deeper, account of Pakistan's industrial policy. It will develop a political economy analysis that transcends beyond proximate causes and traces the evolution of business development in Pakistan from the pre-1947 era.

The paper discusses the political and historical underpinnings of trade and industrial policies in Pakistan. It is based on the premise that current industrial performance is deeply embedded in long standing structures that have remained largely unchanged despite superficial change in policies at the top. The paper sketches the role of initial conditions, such as low levels of urbanization and out-migration of bourgeoisie at the time of independence. It documents ways in which policies are used to create advantages for incumbent elites, rents are generated for business and political elites and special interests are insulated from competitive pressures of domestic and foreign markets. It also investigates the role of foreign aid in distorting industrial structure and emasculating private manufacturing activity.

Taking a time span for this analysis that goes beyond the reach of most social science discussions of developments in Pakistan, the paper hopes to provide a 'long view' perspective and approach. The longer historical perspective, in contrast to a post-1947 baseline, can enhance our understanding of the real degree of continuity and entrenchment of some of the deeper forces shaping this region. Seen then as a package of interactions, the true impact of these forces, and the ways in which their activities and responses have been articulated, can be better assessed. 


\section{The Pre-1947 Mainsprings of Business Development}

Historical developments in the pre-1947 period can have farreaching consequences for the emergence and development of business in the area that currently constitutes Pakistan. It is pertinent to divide the pre1947 period into colonial era and the period immediately preceding British colonial rule.

\section{- The Pre-Colonial Context}

A couple of observations can set the pre-colonial context in which both colonial policies and conditions for subsequent business development were shaped. As argued in Ali (2005), social revolutions in the eighteenth century had long term impacts on the territories that became Pakistan. During the decline phase and eventual eclipse of the Mughal empire, the upper Indus basin, especially the region known in British colonial times as the province of Punjab, experienced great violence and instability. Peasant and lower zamindar rebellions gathered strength as Mughal power waned. Accordingly, the regional elite aligned to Mughal administration came under increasing pressure, and finally succumbed to the rebellion 'from below'. The insurrections were primarily aimed at the onerous revenue-rent exactions, and patterns of elite over-consumption, that were straining the agrarian economy. The final displacement of the older elite had major repercussions on the way in which the encroaching British colonial power interacted with the Punjabi agrarian hierarchy, in contrast to other parts of northern India.

It is possible that the instabilities of the eighteenth century could also have been exacerbated by the spread of the market economy. Apart from revenue and rental exactions by the state and its functionaries, a further impetus to the anti-state rebellions could have come from 'real' economic changes. Some of these could have been the increasing monetization of economy, the higher incidence of commercial farming, the growth in demand for agricultural commodities with greater urbanization and economic specialization, and the growing need for agricultural credit to service cash cropping and the state revenue demand. These trends could have led to a higher incidence of indebtedness, and consequently even encroachments on agricultural landholding rights and occupancy. These pressures could have been exerted by 'non-agriculturist' financiers and moneylenders. These elements could then have exercised forms of mortgage foreclosure, perhaps not so much through law as through strong arm tactics. In lieu of debt repayments, they could also have appropriated producers' marketable surpluses, with a consequent loss of producers' margins. On the 
other hand, more aggressive, efficient and commercialized agriculturists could have created destabilizing inroads into the agrarian economy, thereby producing further strains on weaker or smaller farmers and on service and laboring castes. It is possible that the sustained, and successful, peasant rebellions may have marked a "counter-revolution" against market forces in this part of South Asia.

Economic growth in the Mughal period was accompanied by agrarian growth and increasing levels of urbanization. In pre-industrial terms, the emergence of a mega-city like Lahore, with a purported population attaining levels of even around half a million souls, was indicative of a buoyant, and growing, urban economy and culture. There were several medium sized cities, which served equally as centers of administration, trade and secondary sector production. Artisanal communities, trading and financing groups, and extensive urban construction that included premium luxury structures, not to speak of sizeable state facilities, marked this urban efflorescence. This entire sector experienced a considerable downturn in the post-Mughal phase, with its major discontinuities of political economy. This retreat contrasted discernibly from the greater buoyancy of urban economies in other ex-provinces of the Mughal empire, where regional kingdoms provided more stable post-Mughal continuities, and a more conducive environment for business activities. Thus, instabilities from the mideighteenth to the mid-nineteenth century may have created an unfavorable context for the development of entrepreneurial skills and business in the Pakistan region.

Another discernable trend was the shift in the "center of gravity" of the macro-economy away from the land based north-western parts of South Asia, towards its western and eastern parts, with a clear sea-borne focus. Up to at least the late nineteenth century, The Indus Basin, marked by a new agrarian frontier, became an economic backwater of sorts. This was in distinct contrast to its earlier strategic position as the import and export base for the long distance and land based trade interactions with Central and Western Asia. As a result, the reduced trade volumes could not sustain entrepreneurs of note and scale in this region. The urban contractions, and consequent falls in market demand, could also have undermined the viability of larger scale enterprise in this area, leaving the field clear for more localized microenterprise. The latter, especially when not equipped with new technologies, was ill-fitted to achieve for this region the goal of economic modernization through innovative business strategies. European merchants in the east and south, however acquisitive or amoral, did represent a force towards economic modernization. This raises an important question: Did the Indus basin, by contrast, relapse into a more feudalistic 
mode, where sheer authority and patronage continued to hold sway for far too long? This is indeed a fascinating question for historians for explore.

\section{- Colonial Formations}

The British colonization of India radically altered the structures of power in the region that currently constitutes Pakistan. The colonial period, especially after the 1857 uprising, was associated with a retreat of market forces and an ascendancy of traditional agrarian gentry. The development of an extensive canal irrigation network in the Punjab and the associated land policies not only benefited agrarian incumbents but also consolidated the power of civil and military bureaucratic elites. This led to the entrenchment of a patronage-based model of governance, which restricted access to economic and political opportunities. These new colonial formations constituted an unpropitious inheritance for both the business and the poor.

The notable aspect of the British colonial rule was the linkages and alliances that were fostered by the colonial administration with agrarian incumbents - the very segments that had achieved the relapse of market forces in the previous regime. The British sought the cooperation of these agrarian incumbents, many belonging to a now autonomous upper peasantry and other new arrivals from peasant ranks, for overcoming their adversaries in the armed struggle of 1857-58. These groups were then co-opted into a reconstituted British Indian army, as the old Bengal army was phased out. These alliances were further consolidated through military requirements for the great game in Afghanistan, converting this region into both a recruiting ground and a logistical base. Militarization was further compounded through the upper and middle agrarian hierarchy playing a major mercenary role in policing many other territories of the British Empire. In return, these segments were conceded proprietary rights in land, recognized as revenue payers, and later enfranchised through political devolution.

These alliances moved colonial policy into a paternalistic mode. The traditional social and economic order was safeguarded, when threatened by capitalistic groups and market forces. The great debate among British officials in the final quarter of the nineteenth century regarding the consequences of indebtedness, land mortgages and threatened land expropriations culminated in the Land Alienation Act of 1901. This legislation seriously curtailed the social market for land purchases, restricting such transfers exclusively to "agricultural castes". By excluding non-agriculturists, the Act thwarted possible challenges from a new, more capitalist class of farmers, thereby constraining, if not aborting, the very processes that had created the agricultural revolution in Britain itself. 
Subsequent legislation, such as the one on mortgage foreclosure, also heavily favored agricultural incumbents, while commercial groups began to be viewed with increasing suspicion. Legislative assemblies also came to be heavily dominated by the landlord nominees of agricultural incumbents, with capitalist groups having virtually no representation.

As a result of canal colonization, one of the largest contiguous canal irrigated tracts in the world were created in Punjab. Control over the new lands was vested predominantly with individuals and social groups of existing landholding status. While richer non-agriculturists could buy land at auctions, or were rewarded for government service, the rural poor and landless were universally excluded from obtaining landholding rights. This further entrenched the upper agrarian segment. Business did grow with the great rise of commercial agriculture, but politically it remained subservient to the upper rural segment and civil and military bureaucracies.

The British agricultural policies in Punjab and the hydraulic society of the Indus basin that emerged from it clearly favored agricultural incumbents. But they also consolidated the power of both the colonial state's civil and military functionaries, reflecting again the relative weakness of business. Through centralized irrigation management, the civil bureaucracy now controlled the valuable and scarce resource, canal water. This gave it important leverage over the production system and its practitioners, a very different positioning from its more passive role under rain-fed agriculture. The bureaucracy also controlled and managed the land grant, land transfer and land acquisition systems that facilitated agricultural production in these vast tracts. For the native, subordinate bureaucracy, the opportunities for graft and rents served as a precursor to its post- 1947 misdemeanors.

The link between land and power was further strengthened by institutionalizing the role of military in land grants. Extensive tracts of land were reserved for retired military personnel and for the breeding and maintenance of military animals. This became an important precursor to the post-1947 exercise of direct political hegemony by the military. The colonial access to resources by the military also continued with alacrity in Pakistan. As Siddiqa (2007) has shown, post-independence military elites have preserved - and even expanded in a major way - these resource rents in a significant manner. The relatively unproductive resource diversions of these major institutional stakeholders constrained the domain for competitive business activities. These developments, taken together, constituted a powerful colonial legacy, which in turn may have shaped parameters of Pakistan's political economy after the country, became independent in 1947. 


\section{The Unfavorable Inheritance: Business after the 1947 Partition}

The year, 1947, when the country became an independent State, proved to be a watershed for business and industrial development in Pakistan. Apart from inheriting an adverse colonial legacy from the British rule, the country witnessed a major shock to business development in the form of (a) outmigration of skilled merchants and business entrepreneurs and (b) relatively insignificant industrial and manufacturing capacity on the eve of partition. We will discuss these in detail before analyzing the impact of this inherited legacy on subsequent business development in Pakistan.

\section{- Migration of Commercial Groups}

There were clear beginnings of agro-processing before 1947 partition. Rural growth had spurred extensive agricultural trade and the expansion of market towns. The commercial groups that ran forward extensions of the agricultural value chain, however, were overwhelmingly non-Muslim. The outmigration of these entrepreneurs in the wake of partition further weakened the already grim investment and business climate in the Indus basin. ${ }^{1}$ In the Pakistani areas there was minimal presence of Muslims in business, trade and commerce. The non-Muslims who controlled the economy emigrated to India at the time of partition. This had a major disruptive effect on business development in the Pakistani areas.

Whatever little industrial capacity that did exist in the new state was in the hands of non-Muslims. Although Muslims were active in trade and commerce in British India, most trade, industry and banking was in the hands of Hindus, Parsees and Europeans. Upper-class Muslims tended to be military officers, government officials or landlords. Business activity among Muslims was confined to certain castes and communities, for whom trade and commerce was a hereditary occupation. In West Pakistan, nearly $80 \%$ of the industrial undertaking prior to the partition belonged to non-Muslims. In the city of Lahore, for example, non-Muslims owned 167 out of 215 indigenously-owned factories and controlled the entire money market. In Karachi $80 \%$ of the landed property and almost all the foreign trade was controlled by non-Muslims. Private business in Karachi was primarily owned by Sindhi and Gujrati - speaking Hindus and Parsees, as well as some Goanese Christians. Europeans dominated the export trade. The limited amount of trade and commerce in Muslim hands was owned mainly by

\footnotetext{
${ }^{1}$ Partition brought a massive transfer of population between India and Pakistan: an exodus of 5 million Hindus and Sikhs to India and an inflow of 6.5 million Muslim refugees to West Pakistan.
} 
Khoja Ismailis and Dawoodi Bohras. Sindhi-speaking Muslims in the Karachi area were rarely involved in trade or commerce. In East Pakistan the picture was even more dismal. Very few Bengali Muslims were engaged in any form of trade, commerce or industry. These sectors were largely controlled by Hindu Marwaris and Europeans.

The Hindu communities which controlled trade, commerce and banking abandoned their businesses and joined the exodus of refugees to India. Before the exodus in 1947, the city of Karachi, for example, had a population of about 600,000 . This population was almost equally divided between Hindus and Muslims. By the time of the 1951 Pakistani census, only 4,400 Hindus were recorded out of a total population of $1,122,405$. Moreover, less than a quarter of this population consisted of pre-Partition Karachi residents.

Arguably, the massive outflow of Hindus commercial castes was partly compensated for by the mass inflow of traditional Muslim trading communities from Bombay and Gujrat. ${ }^{2}$ Nevertheless, these new immigrants faced the difficulties of settling and establishing themselves in a new milieu. Partition had resulted in severe rioting and looting in the predominantly Muslim areas of Kathiawar and Cutch in India, and had created uncertainties among Muslim trading communities in Bombay, Calcutta and elsewhere. As a result, large numbers of Memons, Bohras and Khojas, which were traditional Muslim trading communities, decided to immigrate to Pakistan. They tended to settle in Karachi, the new capital and major port city of the country. These immigrants not only took over the commercial establishments abandoned by the non-Muslims who had fled at partition, but also started new businesses at their own initiative.

The 1argest community to immigrate to Pakistan (about 100,000) was the Halai Memons from Gujrat. These Memons were Sunni Muslims of the Hanafi School and were known for their specialization in the kirana and textile trades. They were extremely cohesive, frugal and hardworking, and had a strong commitment to their traditional occupation of commerce, either as employees or as entrepreneurs. The Memons, settling largely in Karachi, moved quickly to fill gaps left by the departing Hindu traders. They took over the textile-importing business, previously the speciality of Hindu traders.

${ }^{2}$ Until the end of 1955 it is estimated that about 7 million refugees entered West Pakistan, and 1.25 million refugees entered East Pakistan, while 5.6 million Hindu and Sikh refugees left Pakistan for India. 
Other traditional Gujrati-speaking trading communities that immigrated to Karachi included the Dawoodi Bohras from Bombay, the Khoja Ismailis from Bombay and East Africa, and the Khoja Ishnaseris. Like the Memons, these communities were hardworking, well-structured, organized in panchayat-like councils, and each had a strong sense of religious solidarity. Unlike the Memons, all three groups belonged to different Shia sects.

Besides the Gujrati-speaking refugee communities, many smaller groups from other parts of the Indian subcontinent also immigrated to Karachi, adding considerable diversity to the city's business community. From Delhi and other parts of Northern India came the Delhi Punjabi Saudagar or Punjabi Sheikhs, an Urdu-speaking trading community. In addition to Karachi, a secondary but important business and industrial center developed around the Lahore-Lyallpur region of the Punjab. The most important trading community to settle in this area were the Chiniotis, a group from the small town of Chiniot near Lyallpur (now Faisalabad). Many Chiniotis had moved to Calcutta during the British period and had become active in the trade of skins and hides. Even before Partition some Chiniotis had moved into the manufacture of leather and rubber goods. Following Partition most Chiniotis returned to Pakistan and began to develop the areas around Lyallpur. Although they were far fewer than the Memons, numbering about 30,000, they were the first to build a textile and consumer goods industry in Pakistan. These patterns of migration provide a vivid illustration of the migratory influences on the spatial distribution of business activity in current day Pakistan.

\section{- A Weak Industrial Base}

In 1947 , industry contributed a mere $1 \%$ of the national income and the worth of Pakistan's industrial assets was a paltry Rs 580 million. The areas that became Pakistan had been considered a granary, which supplied agricultural products to other parts of India, which were in turn dependent on these other regions for their basic supply of manufactures and consumer goods. Serving as an agricultural hinterland, these areas produced cotton and jute which were processed in industrial regions of the Indian subcontinent. West Pakistan, which had been one of the major cottongrowing regions of British India, had only three small cotton textile mills in 1947. Similarly, although East Pakistan produced $70 \%$ of the raw jute in undivided India, it did not have a single jute mill. Overall, except for some cement production and minor industries like food products, sporting goods, and surgical instruments, the Pakistani areas had no modern industry of any significance. 
This almost total absence of modern industry in the Pakistani areas is evident from the geographic distribution of factories in undivided India. In 1947, industries using electrical power and employing at least 20 workers contributed only $1 \%$ of the national income in the Pakistani areas and most of these factories were located in United India. Only 1,414 or $9.69 \%$ were located in the Pakistani territory. Of these, $41.2 \%$ were small-scale establishments, such as flour and rice mills and cotton ginning factories, for the processing of food gains and agricultural raw materials.

\section{The Evolution of Industry since Partition: An Overview}

In the first two decades, industrial growth became a major policy imperative. Despite the government's incentives, the private sector was slow to move into industry in earlier years. Trading was more profitable, especially during the Korean War boom, from 1950 to early 1952. The Korean War led to large increases in the prices of raw materials in foreign markets, especially for raw jute and raw cotton. Since trading had become so profitable in this period, the government relaxed the quantitative controls on trade introduced earlier, leading to a more liberal trade policy. The newly-established Pakistani trading classes benefited greatly. They bought raw materials from the agricultural sector at cheap prices, because food and agricultural raw material prices were kept artificially low by the government through price controls. The traders then sold these raw materials in foreign markets at very high prices, making windfall profits.

The Korean War boom led to the emergence of a large group of traders in Pakistan. Muslims who had dealt on a small scale in grains, spices or cloth found their opportunities greatly increased at Partition with the removal of Hindu and British competition. With export earnings and imports expending rapidly, the abler among them began to operate on a very large scale, expending foreign contacts and establishing large-scale bookkeeping, accounting, control and other management procedures. The Korean War boom enabled Pakistani businessmen to accumulate large cash reserves, facilitating the transition from merchant to industrial capital that began to occur after 1952 .

With the collapse of the Korean War boom the government, fearing a foreign exchange crisis as export prices fell, reimposed controls. These controls on both exports and imports were maintained throughout the 1950 s. In comparison with other sectors of the economy such as agriculture and trading, after 1952, industry became the most profitable sector. Traders who had earlier made high profits and accumulated reserves during the Korean War boom began to convert merchant capital into industrial capital. 
They imported industrial machinery and went into the production of consumer goods, especially cotton textiles. These capital imports were made possible by the foreign exchange reserves built up during the boom. Owing to the low levels it started from, industrial growth witnessed a major expansion from 1949-50 to 1954-55, as the large-scale manufacturing sector in West Pakistan grew at an annual rate of $34 \%$ per year. This growth slowed to $12.4 \%$ from $1954-55$ to $1959-60$. This, in part, made possible a considerable increase in the rate of capital inflow, including aid, into the country, which increased from about $2.5 \%$ of GNP in the mid-fifties to about $7 \%$ in the mid-sixties.

In the early 1950 s the rate of return on industrial investment was so high that industrialists were able to recover their initial investments in a period of one or two years. This incentive to reinvest was therefore considerable, and the large profits made were saved and reinvested in industry. Hence, in the early 1950 s a very high rate of growth was experienced in the industrial sector. This initial substitution phase of Pakistani industrial development was led by cotton textiles in the West and jute production in the East. The protagonists of industrial growth were a small group of industrial families, the majority of which belonged to minority communities, who had immigrated to Pakistan at the time of Partition. An important aspect of industrial growth in this period was that it was achieved at the expense of agriculture. Estimates of terms of trade between industry and agriculture at world prices show that agricultural prices in Pakistan during the 1950 s were $50 \%$ to $70 \%$ lower than world prices, while prices of manufactured goods were considerably higher than world prices.

Business and investment decisions were significantly influenced by state intervention. The Government controlled the foreign exchange and issued import licenses. By its decisions the government determined the success or failure of any venture, and the key to a businessman's success was his access to government channels. Financial infrastructure was almost nonexistent. Given the rudimentary nature of the organized capital market and the willingness of entrepreneurs to pool their interests with other families, projects were limited by the capital available to any one family. Public agencies, such as the PIDC, were created to fill this financing gap. These agencies, however, had a tendency to support the larger, more established enterprises which had good security and a known high rate of profit. For instance, in its policy of disinvestment in projects, the Pakistan Industrial Development Corporation (PIDC) was believed to have favored established industrial families. The Adamjee family, which emerged as the biggest industrial house at the end of the 1950s and established a dominant 
position in the jute industry, was said to have achieved this position through association with the PIDC. Other leading business families like the Saigol, Ispahani, Amin and Crescent groups were also major beneficiaries.

The characteristics of the business community and the political system as they evolved in the early years resulted in the emergence of a business-government relationship based on individual rather than collective action. The character of the political system, with its centralization of power in the hands of the executive, also sought to control groups rather than use them as an effective liaison with society. This further discouraged collective action. In the economic arena, the bureaucracy favored policies involving bureaucratic control of scarce resources and regulation of the economy. The bureaucracy viewed the private entrepreneur with distrust and saw itself as the guardian of the national interest. Bureaucrats thus acted in ways that enhanced their roles in the politico-economic system, and this discouraged collective action.

This tendency resulted in a pattern of access to government and influence based on individual connections rather than in the form of modern organized interest groups. Access to government was built on a highly-complex system of personal contacts designed to secure these benefits. Inevitably, it was the more established business families which benefited most. In Pakistan the caste-like feature of Muslim business groups tended to further isolate them from the rest of society. The merchant refugee of 1947 had little political power, was distrusted by the civil service, and had to deal with government as a supplicant in order to secure the right to practice his trade.

At the end of the first phase of industrialization, the role of government policies and industrial structure came to the fore. The 1950s witnessed direct economic controls on imports, new investments and prices of domestically produced manufactured goods. These controls were considered to be not only economically inefficient, but also a source of corruption. The Ayub government dismantled these controls prices in the 1960s, liberalized trade and encouraged new investments. The main encouragement to exports came through a export-bonus scheme, introduced in 1959, which in effect provided a subsidy for exports and a limited free market for imports. ${ }^{3}$

\footnotetext{
3 "Exporters whose commodities were covered by the scheme received a voucher equal to $10 \%$ to $40 \%$ of the value of their exports. This voucher could be freely sold and entitled the holder to purchase an equivalent amount of foreign exchange to be used for import of
} 
The leading business families, or monopoly houses, were the principal agents that undertook most of the industrial investment in this period. An important feature of the corporate environment during the sixties was the close linkage between industrial and financial capital. The monopoly houses controlled both banks and insurance companies, and were influential in the running of the main aid disbursing agency, Pakistan Industrial Credit and Investment Corporation (PICIC). Of the 17 banks incorporated in Pakistan, seven were under the direct control of the monopoly houses. These banks accounted for about $60 \%$ of total deposits and $50 \%$ of the loans and advances made by all banks operating in Pakistan, including 19 foreign owned banks. The monopoly houses also controlled a large share of the assets of the insurance companies. There were 47 Pakistani insurance companies in 1969 , of which 14 were controlled by the monopoly houses. Their share came to over $50 \%$ of assets of all insurance companies.

Besides their control over the banking and insurance sectors, the monopoly houses were also represented on the boards of a number of important financial institutions, including those controlled by the government. Extremely important were the links which the monopoly houses had with PICIC, the principal foreign aid loan disbursing agency in the country. Seven leading monopoly houses were represented on the board of PICIC, while one of them, Adamjee, was the chairman. It is perhaps not surprising that almost $65 \%$ of total loan disbursed by PICIC from its inception in 1958 uptil 1970 went to 37 monopoly houses, with 13 of the larger monopoly houses getting $70 \%$ of this amount.

The growing industrial concentration, together with the capitalintensive nature of ISI policies led to worsening of income and regional inequalities. Grievances increased over distorted markets, protection of industrial inefficiencies and the growing political influence of vested industrial interests (Kochanek 1983). Commercial and industrial growth in Pakistan was imbalanced, and was undertaken by elements that not only had weak social and political entrenchment, but which did little to build strategic alliances with a wider social base. Business in Pakistan was taken in hand by two groups: commercial castes in Karachi that had migrated from western India, and some upcountry groups returning essentially from the leather trade in Indian Territory. The politically dominant rural hierarchy was clearly discomfited when some of these families appeared to acquire wealth rapidly, through trade surpluses and induced industrialization. More

items on the bonus list.” Given the scarcity of foreign exchange, such vouchers usually sold at a premium of $150 \%$ to $180 \%$ of their face value. 
tellingly, the upper peasantry was also squeezed, as industrial growth was predicated on control of agricultural prices, an overvalued exchange rate that reduced agricultural export earnings but helped capital goods imports, several other forms of incentives and subsidies, and a protected market for overpriced manufactured goods. Moreover, the Green Revolution inputs of the 1960s marginalized the smaller farmers, while tenant expropriation under military rule damaged the moral economy. The business community, instead of building political organizations and strategic alliances that might have secured their position, made their wager with Ayub Khan's military dictatorship.

The consequence of inequity and rapid industrial wealth concentration was the 'counter-revolution' of the 1970s, in which private enterprise experienced major reverses and downturns. The election of 1970 not only broke up Pakistan as a single nation, but it represented also a successful coalition of forces against large-scale business enterprise. The Peoples Party under Z.A. Bhutto combined the upper peasantry in Punjab, riling under the Green Revolution; the landed magnates of Sindh, perturbed by the economic threat from the nouveau riche of Karachi; the intelligentsia and socialists, affronted by the loss of civil and labor rights under Ayub; and the smaller and unorganized sector, alienated by policy discriminations in favor of big business. The sweeping nationalization of much of large-scale enterprise under Bhutto effectively stifled and retarded the high ground of business, and it is doubtful whether investor behavior has even now returned to normality. Moreover, Bhutto later imposed state owned enterprises on agricultural trade, as in wheat procurement and cotton and rice exports. He then began to nationalize the intermediate level agroprocessing operations, for flour, cotton, rice and edible fats. By bringing in public sector managers to these enterprises, he endeavored to placate agriculture producers by thwarting those market functionaries that they had traditionally resented and feared.

In political economy terms, Bhutto's socialistic interventions on the surface may have stemmed from "feudal" concerns over a rapidly emerging industrial class. Nationalization then proved the resilience of the agrarian hierarchy. It transpired that under Bhutto state interventions were pitted decisively against market functionaries rather than semi feudal interests. Bhutto's nationalization also halted the process of diversification that some of the industrial groups were gradually attempting. Interestingly, the largescale nationalization of Bhutto excluded the textile sector, which also happened to be a major industrial buyer of agricultural produce. The industry was not nationalized by Bhutto since it was procurer of a major cash crop, cotton. The private sector took a major battering during the 
Bhutto years and this was evident in the decline in investment rates during the 1970s.

From around 1985, investment levels did pick up, though these were mostly concentrated in the lower value added textile segments of spinning and weaving. The new entrants benefited from pricing anomalies on which this industry has historically thrived, based on depressing the domestic price of cotton below international rates, thereby providing a subsidy to the processor. Cotton textiles assumed a primacy in Pakistani industry. After 1985, the textile "lobby" further strengthened through new investment and incentives. Pakistan relied heavily on this staple commodity, with nearly two thirds of total exports in cotton-based products. This lack of diversification in the economy accentuated structural weaknesses. Most of the new textile projects were over-leveraged, with investor risk reduced by transferring much or all of owners' equity offshore such stratagems as over invoicing of machinery imports. Such malpractices led to bad loan portfolios that virtually bankrupted banking and financial institutions in the country. Malpractice and rent seeking, as in the past, marked the emergence of this latest wave of industrial entrepreneurs. Several of them entered politics and prospered rapidly, among them the Sharifs of the Ittefaq Group, the Chaudhries of Gujrat and sons of some corrupt generals of the Zia regime.

Since 1990, Pakistan did embark on a "liberalization" program. The stimulus for this came from external sources. Although unsuccessful in increasing overall investment, the major privatization and deregulation programs of the 1990s changed the balance between public and private sector investment. The private sector's share of total capital increased from $48 \%$ in 1988 to $57 \%$ in 1999 . Most of the private investment occurred in the manufacturing sector, and over $90 \%$ of it was in the large-scale sector. Private investment increased from $8 \%$ of GDP to a peak of $10 \%$ of GDP in the early 1990s. In absolute terms private investment increased approximately fourfold from 1988 to 1999 .

The textile industry had a mixed performance in the 1990s. Cotton textiles continued to account for $60 \%$ of Pakistan's exports in the period. Overall cotton yarn production grew at an average of $7 \%$ per year during the period 1988-99, and cloth production grew at 3\% per year. Pakistan's textile products captured just $2 \%$ of the global market, unable to compete with rivals like Hong Kong and the Philippines in the value-added textile sector, or high- quality finished garments rather than coarse yarn and cloth. Cotton exports stagnated at growth rates of $1 \%$ per annum in the mid 1990 s, soon translating into a slowdown in yarn production towards the end of the decade. 
The sugar industry became a key arena of state patronage in the 1990s, and politically motivated decision making led to a profusion of underutilized sugar mills. In 1988 there were 45 sugar mills in the country, with a refining capacity of 1.26 million tones. As a result of a bumper sugarcane crop after unusually heavy rainfalls that year, the mills were running overcapacity. By 1999, the country had 78 sugar mills with a combined production capacity of 5 million tones, but running at only a $45 \%$ utilization rate. The raw inputs for the sugar-refining industry were supplied by domestic sugarcane agriculture, which is a water-intensive farming not well suited to Pakistan's dry climate. Despite this, sugarcane cultivation in the 1990s enjoyed higher protection rates than wheat, rice, and cotton, and hence was disproportionately grown by farmers. By 1999 Pakistan was the fourth largest sugarcane grower in the world in terms of area under production, but ranked fifteenth in yield per hectare.

A major stimulus to the rapid expansion of the sugar mill capacity was the fact that the Sharif family's Ittefaq Foundry was a major capital goods supplier to the sugar industry. Nawaz Sharifs efforts to cajole banks and development financial institutions (DFIs) into channeling credit flows towards investment in sugar production underlay this unhealthy trend towards overcapacity in sugar. Furthermore, domestic sugar prices had traditionally remained above international prices, a product of the relative inefficiency of the local sugar production. Thus, higher priced sugar represented a resource transfer from consumers to sugar processors and sugarcane farmers, a process exacerbated by an ecologically maladjusted but rapid and politically induced rise in sugar production. Not surprisingly, permission for setting up sugar plants came to be seen as a pay-off for political support and a sign of crony capitalism.

Programs for deregulation, privatization, and overall liberalization of the private sector took place rapidly during Nawaz Sharifs first term (1990-93) but lost steam thereafter. The opening up of the economy created opportunities for the emergency of a vigorous, independent entrepreneurial class as the organizers of economic activity in the country. Sharifs privatization program was criticized for lack of transparency, corruption and concentration of wealth in a few hands. Privatization had resulted in a monopoly in the cement market, as five cement factories were all privatized to Mian Mansha (who also got Muslim Commercial Bank (MCB)). Another major beneficiary, the Schon Group, got Pak-China fertilizer and National Fibre, and Sikandar Jatoi got Metropolitan Steel, Zeal Pak Cement, and Shikarpur Rice. When Sharif was dismissed on April 18, 1993, the Dissolution Order listed "the lack of transparency in the process of privatization and in the disposal of public/government properties" as one of the grounds for dismissal. Although the Supreme Court restored the 
Sharif government, the judges found the privatization program to be defective and in conflict with the provisions of the constitution.

A study undertaken by the Asian Development Bank showed that after privatization only $22 \%$ of the privatized units performed better than they had under state ownership and 34\% were performing worse. Even more seriously, 20 privatized units had been closed after privatization, including three cement units and five ghee/vegetable oil units. Many buyers had been interested primarily in stripping manufacturing assets rather than running them. All the engineering units except Millat and A1-Ghazi tractors were closed, as the buyers lacked the management and technical expertise.

A significant development during the 1990s was the abuse of the financial sector for generating rents for political incumbents. The alliance between banking officials, government bureaucracy, and the industrialist class created serious distortions in the management of the private sector. Bank loan defaults first became a major public issue when the caretaker government of Moeen Qureshi published a list of defaulters in the daily Dawn, showing an outstanding amount of Rs. 80 billion. Over the rest of the 1990s, the outstanding amount continued to mushroom despite muchpublicized loan recovery drives by successive governments. By the end of 1999, the total outstanding amount was estimated at Rs. 300 billion. The State Bank of Pakistan offered incentives such as the repayment of only the principal plus interest of only $5 \%$ of the principal, in lieu of the full amount of accrued interest. However, even these incentive plans had only a $30-40 \%$ response ratio and the majority of defaulters never surfaced.

The worst-hit lending institutions were the nationalized banks and the DFIs, respectively accounting for an estimated $60 \%$ and $20 \%$ of the total defaulted loans. The high incidence of defaults at these institutions highlighted the serious shortcomings in their credit assessment procedures. Bad loans as a percent of loan portfolios were $23 \%$ at DFIs and $28 \%$ at nationalized banks, versus the much lower 13\% at privatized banks and $5 \%$ at new Pakistani banks. At the nationalized banks and DFIs, loan issuance seemed to be based on political motivations rather than economic viability assessments. In many cases, capital costs were over-invoiced to funnel borrowed cash into individuals' pockets. When the banks later foreclosed on defaulters' assets, they had poor recovery on collateral assets that had been over-invoiced. Even in the cases where there appears to be no active connivance or corruption of bankers and industrialists, lax banking officials approved borrowers with obsolete technology, inadequate technical expertise, and unproven management skills. 
The burgeoning loan defaults in the 1990s reflected a huge missed opportunity for the private sector in Pakistan. Used as instruments of state patronage, nationalized banks and DFIs created a rich defaulter class whose wealth ended up in the black economy, or in most cases simply left Pakistan altogether. Instead of fuelling growth, many valuable economic resources were blocked in malafide or poorly planned enterprise. The high incidence of bad loans at nationalized banks, such as United Bank and Habib Bank, severely hampered the intended privatization of the banking sector.

In 1991, Nawaz Sharif ended restrictions on foreign investment in shares of Pakistani companies, and removed constraints on the repatriation of investment gains and dividends. The stock market expended rapidly in the early 1990s, with aggregate market capitalization growing fivefold from 1990 to 1994. The privatization of state enterprises and liberalization of foreign investment were the major growth drivers. Deregulation to 100 percent foreign ownership of some state enterprises and an aggressive timetable for further privatization of the economy drove foreign investors' enthusiasm. Between June 1991 and 1995 , net portfolio inflows of $\$ 3.3$ billion were recorded, mostly from institutional investors in Hong Kong and Singapore.

Private sector growth was heavily driven by patronage from the government's privatization drive rather than by original entrepreneurial activity, as evidenced by the reduction in mobilized funds from new company issuances after the show-down of the privatization program. The obsolete technology of the Karachi and Lahore Stock Exchanges prevented transparency or efficiency of transaction processing, and the market was rife with anecdotes of insider trading. However, as a system for encouraging public investment, the stock market failed to penetrate the smaller and middle-class investors and remained the domain of foreign mutual funds and domestic speculators.

Compared to the slack in democratic years, economic growth picked up during Musharrafs rule aided by the resumption of aid flows in 2001. The rapid rise in liquidity had a visible impact on Pakistan's economy. There was a sharp reduction of interest rates, which led to an increase in consumption and a second-order effect on investment to meet the growing demand for goods and services. Musharrafs period was marked by growing presence of military corporate interests and a boom in real estate and stock markets. The asset boom allegedly diverted industrialists towards raising bank credit for quick returns on property speculation. The main agents of accumulation during this period were the top echelons of military bureaucracy, real estate developers, stock brokers and financial services industry. 


\section{Conclusion}

- Structural weaknesses place Pakistan in a relative disadvantage in times of globalization

- Pakistan chosen by forces of globalization, not for its wealth generating virtues, but geo-strategic imperatives

- Pakistan is not landlocked or remote, but addicted to geo-strategic rents (foreign aid) 


\section{References}

Ahmad, V., and Amjad, R. (1986). The Management of Pakistan's Economy, 1947-82. Oxford University Press: Karachi.

Alam, M. (1986). The Crisis of Empire in Mughal North India: Awadh and Punjab, 1707-48. Oxford University Press: Delhi.

Ali, I. (2003). The Punjab under Imperialism, 1885-1947. Oxford University Press: Karachi.

Ali, I. (2004). Historical Impacts on Political Economy in Pakistan. Asian Journal of Management Cases, Vol. 1(2): 129-146.

Ali, I. and Mumtaz, S. (2002). The Historical Lineages of Poverty and Exclusion in Pakistan, South Asia. Journal of South Asian Studies, Vol. 25(2).

Amjad, R. (1982). Private Industrial Investment in Pakistan, 1960-1970. Cambridge University Press: London.

Andrus, J.R., and Mohammed, A.F. (1958). The Economy of Pakistan. Cambridge University Press: London.

Barrier, N.G. (1966). The Punjab Alienation of Land Bill of 1900. Duke University: Durham, NC.

Baxter, C. (ed.) (1985). Zia's Pakistan: Politics and Stability in a Frontline State. Westview Press: Boulder, Colorado.

Bayly, C. A. (1983). Rulers, Townsmen and Bazaars. In North Indian Society in the Age of British Expansion, 1770-1870. Cambridge [Cambridgeshire]; New York : Cambridge University Press.

Burki, S.J. (1980). Pakistan under Bhutto: 1971-77. London: Macmillan.

Burki, S.J. and Baxter, C. (1991). Pakistan under the Military: Eleven Years of Zia ul-Haq. Westview Press: Boulder, Colorado.

Banga, I. (ed). (1997). Canal Colonization and Socio-Economic Change, in Five Punjabi Centuries: Polity, Economy, Society and Culture, c. 1500-1990. 
Habib, I. (1963). The Agrarian System of Mughal India. Asia Publishing House: London.

Hasan, P. (1998). Pakistan's Economy at the Crossroads: Past Policies and Present Imperatives. Oxford University Press: Karachi.

Husain, I. (1999). Pakistan : The Economy of an Elitist State. Oxford University Press, Karachi

Kessinger, T.G. (1974). Vilyatpur, 1848-1968. University of California Press: Berkeley and Los Angeles.

Khan, S.R. (ed) (1999). Fifty Years of Pakistan's Economy: Traditional Topics and Contemporary Concerns. Oxford University Press: Karachi.

Kibria, G. (1999). Shattered Dream: Understanding Pakistan's Development. Oxford University Press: Karachi.

Kochanek, S.A. (1983). Interest Groups and Development: Business and Politics in Pakistan. Oxford University Press: New Delhi.

Kumar, D. (1982). The Cambridge Economic History of India. Cambridge University Press: Cambridge.

LaPorte, R. Jr., and Ahmad, M.B. (1989). Public Enterprises in Pakistan. Westview Press: Boulder, Colorado.

Latif, S.M. (1892). Lahore. New Imperial Press: Lahore (reprinted 1981).

Mumtaz, S., Racine, J.L., and Ali, I. (eds) (2002). Pakistan: The Contours of State and Society. Oxford University Press: Karachi.

Mumtaz, S., Racine, J.L., and Ali, I. (eds) (2002). Understanding Pakistan The Impact of Global, Regional, National and Local Interactions, in Pakistan: The Contours of State and Society. Oxford University Press: Karachi.

Noman, O. (1988). The Political Economy of Pakistan. Kegan Paul International: London.

P.H.M. van den Dungen (1972). The Punjab Tradition. Oxford University Press: London. 
Papanek, G.F. (1967). Pakistan's Development: Social Goals and Private Incentives. Cambridge: Massachusets.

Weiss, A.M., and Gilani, S.Z. (eds). (2001). Business and Power in Pakistan (2001). In, Power and Civil Society in Pakistan. Oxford University Press: Karachi.

White, L.J. (1974). Industrial Concentration and Economic Power. Princeton University Press: N.J.

Zaidi, A. (1999). Issues in Pakistan's Economy. Oxford University Press: Karachi.

Ziring, L. (1971). The Ayub Khan Era: Politics in Pakistan, 1958-1969. Syracuse University Press: Newyork.

Ziring, L. (1980). Pakistan: The Enigma of Political Development. Westview Press: Boulder Colorado. 